\title{
KEGIATAN MEMBACA LEBIH UNGGUL DARIPADA MENONTON DALAM MELATIH KETERAMPILAN BERPIKIR KRITIS ANAK
}

\author{
${ }^{1}$ Shofia Hattarina, ${ }^{2}$ Hendra Pratama, ${ }^{3}$ Linda Kurnia Supraptiningsih \\ 1,2,3 Universitas Panca Marga Probolinggo \\ Corresponding Email: shofiahattarina@gmail.com
}

Received: Nov 10, 2020

Revised: Nov 12, 2020

Accepted: Nov 16, 2020

\begin{abstract}
ABSTRAK
Tujuan dari penulisan artikel ini adalah menemukan data dan fakta yang mendukung bahwa kegiatan membaca lebih baik daripada menonton dalam meningkatkan skill berpikir kritis seorang anak. Penulisan artikel ilmiah ini menggunakan metode studi literatur dengan menggunakan berbagai jenis sumber baik dari buku, artikel ilmiah dari berbagai jurnal untuk mencari teori dan data-data yang mendukung. Kesimpulan dari tulisan ini adalah bahwa Jika anak hanya terbiasa menonton maka kemampuan menulisnya tidak akan sebaik anak yang gemar membaca. Dengan kegiatan membaca imajinasi seseorang bisa semakin terlatih dibanding dengan yang sekedar menjadi penonton. Dan anak yang gemar membaca keterampilan berpikir kritisnya lebih terasah daripada anak yang hanya menonton.
\end{abstract}

Kata kunci: Membaca, Menonton, Berpikir Kritis

\begin{abstract}
The purpose of writing this article is to find data and facts that support reading activities better than watching in improving a child's critical thinking skills. The writing of scientific articles uses the literature study method using various types of sources, from books, scientific articles from various joumals to find supporting theories and data. The conclusion of this paper is that if children are only used to watching, their writing skills will not be as good as children who like to read. By reading someone's imagination can be more trained than just being an audience. And children who like to read have more honed critical thinking skills than children who just watch.
\end{abstract}

Keywords: Reading, Watching, Critical Thinking

\section{PENDAHULUAN}

Mempersiapkan anak didik untuk mampu bersaing secara global di masa yang akan datang merupakan tantangan tersendiri yang harus dihadapi dunia pendidikan. Di masa depan akan banyak bermunculan profesi-profesi dan pekerjaan-pekerjaan yang belum ada atau belum ditemui pada saat ini. Begitu pula halnya pada jaman dahulu tidak ditemui beberapa profesi-profesi atau pekerjaan yang ada pada saat ini. Dari pola gambaran ini dapat 
disimpulkan bahwasanya setiap jaman akan selalu berkembang dan melahirkan inovasiinovasi baru dalam berbagai bidang dan tentu saja menuntut profesi-profesi baru untuk menopangnya. Di sinilah peran pendidikan dalam mempersiapkan generasi-generasi penerus bangsa untuk dapat ikut mengambil peran dan survive bersaing secara global menghadapi kemajuan-kemajuan jaman di masa yang akan datang yang belum pernah terprediksi.

Salah satu langkah yang perlu diambil dunia pendidikan di Indonesia untuk mensejajarkan diri dengan standar pendidikan dunia yaitu bisa dimulai dengan peningkatan budaya literasi. Menurut hasil penelitian PISA menyimpulkan tingkat literasi anak-anak di Indonesia berada di rangking ke 62 dari 70 negara yang disurvey. Padahal budaya literasi ini sangat penting dan menjadi modal utama setiap anak untuk mendapatkan pengetahuan dan keterampilan baru.

Kegiatan membaca saat ini menjadi semakin terkalahkan dengan kegiatan menonton. Sudah menjadi fenomena jika saat ini anak-anak lebih suka menonton lewat gadgetnya daripada membaca buku cerita. Kedua kegiatan ini tentu saja sangat berbeda jika dilihat secara keaktifan kognitif. Membaca adalah kegiatan yang aktif, sedangkan menonton adalah kegiatan pasif. Ketika membaca seluruh sensor kognitif terlibat dalam kegiatan yang kompleks. Beberapa kegiatan kognitif yang berlangsung selama membaca diantaranya yaitu, memahami, konsentrasi, mengingat, menganalisis, menyimpulkan dan lain sebagainya, yang mana juga merupakan aspek-aspek dari berpikir kritis. Membaca dalam bahasa Arab berarti "qa-ra-a" yang artinya "menghimpun" karena ketika membaca indera mata kita menghimpun huruf demi huruf, kata demi kata, selanjutnya otak memaknainya lalu diteruskan dan disimpan ke dalam memori jangka pendek untuk selanjutnya disimpan secara permanen dalam memori jangka panjang dengan usaha-usaha tertentu.

Sedangkan kegiatan menonton secara kognitif anak lebih banyak pasif menerima input tanpa menghasilkan output. Ketika kegiatan menonton berlangsung otak tidak dirangsang untuk berpikir. Otak hanya bertindak pasif dan konsumtif menerima informasi. Otak tidak dirangsang untuk menginterpretasikan atas informasi yang diberikan, sehingga kemampuan imajinasi anak kurang berkembang.

Beberapa hasil penelitian terdahulu juga mendukung adanya bahwa kebiasaan membaca dapat membantu meningkatkan skill bepikir kritis anak. Kemampuan membaca kritis berperan aktif dalam peningkatan kemampuan pengambilan keputusan. Keterampilan dalam mengambil keputusan ini perlu dimiliki oleh setiap siswa dan sangat berdampak positif dalam pembelajaran maupun dalam kehidupan sehari-hari siswa (Zaini, 2015). Ada hubungan yang positif dan sangat signifikan kemampuan membaca buku teks dengan 
keterampilan berpikir kritis siswa secara bersama-sama dengan hasil belajar siswa di SMP 2 Cimanuk Kabupaten Pandeglang pada mata pelajaran PAI (Fitrah, 2017).

Beberapa indikator yang mengindikasikan kemampuan berpikir kritis seseorang seperti yang diungkapkan Ennis (dalam Komalasari 2010: 267- 268) diantaranya yaitu: 1) mampu menyampaikan penjelasan sederhana, hal ini berarti dia mampu menangkap fokus dari pertanyaan, menganalisa argumentasi, bertanya atau menjawab suatu statemen atau tantangan. 2) mengkonstruk kemampuan dasar, diantaranya menilai kredibilitas sumber, melakukan sebuah observasi dan membuat prediksi hasil observasi. 3) membuat kesimpulan, membuat induksi, memprediksi hasil induksi. 4) memberikan penjelasan lebih lanjut, mendefinisikan sebuah istilah, mengidientifikasi sebuah asumsi. 4) memanage sebuah strategi, meliputi pengambilan keputusan, berinteraksi dengan yang lain.

Indikator-indikator berpikir kritis tersebut di atas dapat ditemukan dan sama ketika seseorang membaca. Jadi kegiatan membaca bisa dikatakan mampu digunakan untuk melatih keterampilan berpikir kritis. Hal ini didukung oleh Madison (dalam Chi An tung, 2009: 291) yang menuliskan jika 'berpikir kritis dapat dilatih melalui membaca. Seorang pembaca perlu memahami bacaannya dan menghubungkan dengan pengalaman yang dimilikinya'. Ketika seorang anak mlakukan kegiatan membaca otomatis dia akan berpikir. Dia akan berpkir bagaimana memahami bacaan tersebut melalui proses asosiasi dan eksperimental, kemudian dia akan membuat kesimpulan dengan menghubungkan preposisi yang ada dalam bacaan tadi. Proses ini tentu menuntut untuk berpikir secara sistematis, logis dan juga kreatif.

Penelitian lain juga menemukan bahwa aktifitas kognitif seperti membaca jika dilakukan secara rutin akan memberikan kontribusi positif pada fungsi kognitif seseorang di masa tuanya (Riani, 2019). Penurunan kognitif pada hari tua sering dikaitkan dengan alzheimer atau penyakit pikun.

\section{METODE}

Penulisan artikel ilmiah ini menggunakan metode studi literatur dengan menggunakan berbagai jenis sumber baik dari buku, artikel ilmiah dari berbagai jurnal untuk mencari teori dan data-data yang mendukung. Penelitian kepustakaan bisa diartikan penelitian yang hanya didasarkan hasil karya tulis baik yang dipublikasikan atau yang tidak dpublikasikan (Embun, 2012). Walaupun disebut dengan penelitian akan tetapi penelitian dengan metode ini tidak harus turun ke lapangan untuk memperoleh data dari responden. Data yang diperlukan dapat diperoleh dari sumber pustaka, artikel, buku, dokumen. 
Lebih lanjut (Zed, 2014) menuliskan pada library research, penelusuran pusaka bukan hanya dilakukan pada awal penelitian sebagai landasan teori dan rancangan penelitian, akan tetapi juga memanfaatkan sumber-sumber pustaka untuk mendapatkan data penelitiannya.

\section{HASIL DAN PEMBAHASAN}

Harjasujana (1994:4) menuliskan bahwa membaca sejatinya sebuah proses. Membaca merupakan sebuah proses yang kompleks yaitu mensintesis dari berbagai aktifitas kognitif yang kompleks menjadi suatu perbuatan yang bersifat tunggal. Membaca disamping melafalkan kata-kata, juga merupakan kegiatan identifikasi kata-kata itu sendiri dan juga mencari makna dan kesimpulan dari sebuah teks. Kegiatan membaca diawali dengan mengindera teks-teks bacaan untuk memaknai dengan logika isi teks tersebut.

Membaca artinya yaitu sebuah proses yang dilaksanakan dan dimanfaatkan oleh seorang pembaca untuk menangkap pesan dan maksud yang dituliskan oleh penulis (Tarigan, 1984:7). Membaca juga berarti suatu cara untuk melatih daya nalar seseorang (Tampubolon, 1987: 6). Melalui membaca anak mengeja kata demi kata, lalu menghubungkan antara arah dan maksud bacaannya, dan yang terakhir membuat sebuah kesimpulan sesuai dengan nalarnya.

Dalam ilmu linguistik membaca mengarah pada kegiatan kognitif penyandian kembali dan juga pembahasan sandi, berlawanan dengan kegiatan menulis dan berbicara yang justru berarti kegiatan menyandikan (encoding). Salah satu aspek proses pembacaan sandi atau membaca adalah mengaitkan kata-kata tulisan kepada makna bahasa lisan, termasuk mengubah tulisan menjadi bunyi yang mempunyai makna (Tarigan, 1984:8).

Dari beberapa definisi di atas dapat ditarik kesimpulan bahwa membaca merupakan kegiatan aktif dari indera visual dengan kegiatan kontitif.

Syafie'i (1994, 6-7) menuliskan tentang hakikat membaca sebenarnya yaitu:

1. Mengembangkan beberapa keterampilan, seperti memaknai kata-kata, kalimat, paragraf, sampai dengan memahami secara kritis dan juga menilai seluruh teks bacaan.

2. Mengaktifkan kegiatan visual, melalui kegiatan membaca mata akan bergerak mengikuti baris-baris kalimat, fokus mata pada bacaan, mengecek ulang kata demi kata untuk menangkap makna dari sebuah bacaan.

3. Sebuah aktifitas memahami maksud kalimat-kalimat yang tertulis serta memaknainya berdasarkan pengalaman dan pengetahuannya terdahulu. 
4. Aktifitas kognitif diantaranya yaitu mempersepsi, memahami dan memaknai bacaan.

5. Sebuah proses mengolah informasi yaitu dengan mengaitkan isi dari bacaan dengan pengetahuan terdahulu yang sudah dimiliki pembaca.

6. Aktifitas mengantisipasi arti dari baris-baris sebuah tulisan. Kegiatan membaca bukan semata kegiatan fisik dari indera penglihatan saja tapi juga merupakan kegiatan kognitif.

Dari ulasan hakekat membaca di atas dapat ditarik sebuah pemahaman bahwasanya kegiatan membaca bukan hanya kegiatan fisik yaitu indera penglihatan yang mengamati tulisan dan proses mekanis membaca. Akan tetapi membaca juga melibatkan kegiatan kognitif berupa pemrosesan informasi. Proses ini dimulai dari memaknai isi bacaan lalu menyimpannya ke dalam memori jangka pendek, lalu diteruskan ke dalam memori jangka panjang. Melalui proses decoding simbol-simbol tulisan itu diidentifikasi, dan diberi makna. Aktifitas decoding berlangsung dengan melibatkan knowledge of the world dengan mengklasifikasi sejumlah informasi dan pengalaman yang tersimpan dalam memori.

\section{Berpikir Kritis}

Elaine B. Jhonson (2009: 183) menulis bahwa berpikir kritis adalah proses yang terarah dari kegiatan mental seperti problem solving, mengambil keputusan, persuasi, analisa asumsi, dan penelitian ilmiah. Berpikir kritis juga termasuk 1)kemampuan menyampaikan pendapat yang terorganisas, 2) kemampuan menilai antara bobot pendapat pribadi dan pendapat orang lain 3) kegiatan mental dalam mendapatkan ide-ide orisinil dan pemahaman baru.

Kemampuan berpikir kritis ini sangat membantu dalam kehidupan sehari-hari seperti pemecahan masalah dan pengambilan keputusan yang benar (Purwati, 2016:84). Manfaat dari beripikir kritis antara lain; 1) Mampu Berpikir Jernih dan Rasional, kemampuan ini menandakan orang tersebut mampu berpikir dengan baik dan dapat menyelesaikan masalah dengan sistematis. Orang yang mampu berpikir kritis adalah aset dalam karir dalam bidang apapun nantinya. 2) kemampuan adaptasi yang baik, di zaman yang serba cepat dalam perkembangan IPTEK akan mudah diadaptasi oleh orang dengan kemampuan berpikir kritis. 3) meningkatkan kreativitas, kreativitas adalah hal yang sangat dihargai pada era 4.0 ini dan orang yang terbiasa beripikir kritis mudah menemukan ide-ide yang baru dan kreatif. 4) pengembangan diri, orang yang berpikir kritis dapat mengevaluasi ide dan keputusan yang telah diambil, sehingga orang yang berpikir kritis cenderung lebih berkembang.

\section{Perbandingan Antara Membaca dan Menonoton Dalam Mengembangkan Keterampilan Berpikir Kritis Anak}


Membaca lebih merangsang otak menyusun informasi yang diterima dalam bentuk yang lebih rapi dan sistematis daripada sekedar menonton. Penyajian pesan lewat bahasa tulis lebih lengkap, runtut, sistematis dan teratur jika dibandingkan dengan penyajian informasi melalui film yang lebih cepat. Anak yang terbiasa menyusun informasi yang diterimanya dengan rapi dan sistematis ketika dewasa kemampuan berbicara dan menulisnya juga lebih runtut, rapi dan sistematis.

Seorang anak yang sudah terbiasa menyerap informasi melalui kegiatan menonton akan mengalami kesulitan jika harus memahami sebuah pesan yang disampaikan melalui bacaan. Sebaliknya anak yang sudah terbiasa membaca sama sekali tidak menemukan kesulitan yang berarti saat dihadapkan dengan pesan yang dikemas berupa tontonan.

Dengan kegiatan membaca imajinasi seseorang bisa semakin terlatih dibanding dengan yang sekedar menjadi penonton. Ketika membaca seseorang dituntut untuk membayangkan dan mengimajinasikan apa yang sedang ia baca. Sedangkan ketika menonton imajinasi tersebut sudah tergambarkan semua dalam layar. Ekspresi, adegan, latar, suasana semua sudah tersajikan penuh dalam film.

Tarigan (2008:4) menuliskan bahwa hubungan antara membaca dan menulis sangatlah erat. Saat menulis sebuah tulisan artinya mempunyai tujuan agar tulisan tadi dibaca oleh orang lain, atau minimal untuk dibaca sendiri pada saat dibutuhkan. Hal ini juga didukung oleh sebuah hasil penelitian yang menyimpulkan bahwa kemampuan seseorang membaca sastra mempengaruhi kemampuannya membuat tulisan karangan narasi (2013: 460). Jika anak hanya terbiasa menonton maka kemampuan menulisnya tidak akan sebaik anak yang gemar membaca.

Indikator-indikator berpikir kritis dapat ditemukan dan sama ketika seseorang membaca. Jadi kegiatan membaca bisa dikatakan mampu digunakan untuk melatih keterampilan berpikir kritis. Hal ini didukung oleh Madison (dalam Chi An tung, 2009: 291) yang menuliskan jika 'berpikir kritis dapat dilatih melalui membaca. Seorang pembaca perlu memahami bacaannya dan menghubungkan dengan pengalaman yang dimilikinya'. Ketika seorang anak mlakukan kegiatan membaca otomatis dia akan berpikir. Dia akan berpkir bagaimana memahami bacaan tersebut melalui proses asosiasi dan eksperimental, kemudian dia akan membuat kesimpulan dengan menghubungkan preposisi yang ada dalam bacaan tadi. Proses ini tentu menuntut untuk berpikir secara sistematis, logis dan juga kreatif. 


\section{KESIMPULAN}

Dari pembahasan di atas dapat disimpulkan bahwa ternyata menonton tidak banyak berpengaruh pada perkembangan otak. Sebaliknya membaca memberi manfaat yang begitu banyak, tidak hanya soal ilmu tapi membaca membantu otak untuk berkembang. Walaupun seorang anak sama-sama menyimak sebuah cerita misalnya, tetapi melalui media yang berbeda yakni video dan buku. Keduanya memperoleh pengalaman aktifitas kognitif yang berbeda. Anak yang membaca buku secara kognitif lebih banyak mengalami latihan memahami, fokus, menganalisa, mengimajinasikan, menyimpulkan dll. Sehingga anak yang membaca buku lebih imajinatif, kreatif dan berpikir kritis. Sedangkan anak yang menonton langsung dari sebuah film secara kognitif cenderung pasif karena tidak banyak membutuhkan fokus, tidak harus menganalisa, tidak harus menyimpulkan, karena semua sudah tersaji di dalam film tersebut secara penuh.

\section{DAFTAR PUSTAKA}

Chi An Tung. 2009. Developing Critical Thingking Through Literature Reading. Feng Chia Journal Humanities and Social Sciences.hlm 5.

Elaine B. Jhonson. 2009. Contextual Teaching \&Learning Menjadikan Kegiatan Belajar Mengajar mengasyikkan dan Bermakna. Bandung: MLC.

Fitriah, Diana. 2017. Hubungan Kemampuan Membaca Buku Teks dan Keterampilan Berpikir Kritis Dengan Hasil Belajar Pendidikan Agama Islam. Studia Didaktika: Jurnal Ilmiah Bidang Pendidikan 11 (1): 91-110.

Komalasari, K. 2010. Pembelajaran Konseptual Konsep dan Aplikasi. Bandung: PT. Radikatama.

Nurhidayah, Istianti. 2018. Pengaruh Kegiatan Membaca Pemahaman Terhadap Kemampuan Berpikir Kritis Siswa Kelas VI SD. Pedadidaktika: Jurnal Ilmiah Guru Sekolah Dasar 5 (3): 192- 202.

Purwati, dkk. 2016. Analisis Kemampuan Berpikir Kritis Siswa Dalam Menyelesaikan Masalah Persamaan Kuadrat Dalam Pembelajaran Model Creative Problem Solving. Kadikma 7 (1): 84-93.

Riani, Adriana Dewi. 2019. Fungsi Kognitif Lansia yang Beraktifitas Kognitif Secara Rutin dan Tidak Rutin. Jurnal Psikologi 46 (2): 850-101.

Semi, M. Atar. 2007. Dasar-dasar Keterampilan Menulis. Bandung: Angkasa.

Soedarso. (2000). Speed Reading:Sistem Membaca Cepat dan Efektif. Jakarta: Gramedia Pustaka Utama

Syafi'ie, Imam. 1999. Pengajaran Membaca Terpadu. Bahan Kursus Pendalaman Materi Guru Inti PKG Bahasa dan Sastra Indonesia. Malang: IKIP. 
Tarigan, Henry Guntur. 1984. Membaca Sebagai Suatu Keterampilan Berbahasa. Bandung: Angkasa.

Tarigan, H.G. (2008). Membaca sebagai Suatu Keterampilan Berbahasa. Bandung: Angkasa

Yeni, Retna. 2013. Hubungan Kemampuan Membaca Sastra Dengan Kemampuan Menulis Karangan Narasi Siswa Kelas X SMA 1 Negeri Lubuk Basung. Jurnal Pendidikan Bahasa dan Sastra Indonesia. 1 (2): 453-460.

Zaini, Muhammad Ramlan. 2015. MENINGKATKAN KEMAMPUAN PENGAMBILAN KEPUTUSAN DENGAN MEMBACA KRITIS. Dalam Prosiding SEMINAR NASIONAL PENDIDIKAN DASAR SPS UPI 2015Membangun Imajinasi dan Kreativitas Anak Melalui Literasi. Bandung: Desember 2015. Hal. 8-12.

Zed, M. 2004. Metode Penelitian Kepustakaan. Jakarta: Yayasan Obor Indonesia. 